This article was downloaded by: [ ]

On: 05 August 2011, At: 03:21

Publisher: Routledge

Informa Ltd Registered in England and Wales Registered Number: 1072954 Registered

office: Mortimer House, 37-41 Mortimer Street, London W1T 3J H, UK

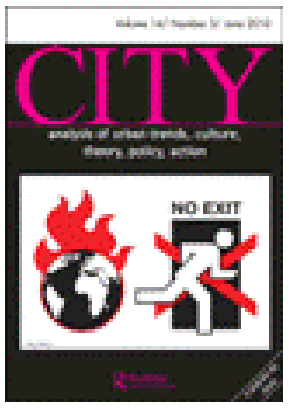

\title{
City
}

Publication details, including instructions for authors and subscription information:

http:// www.tandfonline.com/loi/ ccit20

\section{Urbanism in the anthropocene: Ecological urbanism or premium ecological enclaves?}

Mike Hodson \& Simon Marvin

Available online: 11 J un 2010

To cite this article: Mike Hodson \& Simon Marvin (2010): Urbanism in the anthropocene: Ecological urbanism or premium ecological enclaves?, City, 14:3, 298-313

To link to this article: http:// dx. doi.org/ 10.1080/13604813.2010.482277

\section{PLEASE SCROLL DOWN FOR ARTICLE}

Full terms and conditions of use: http://www.tandfonline.com/page/terms-andconditions

This article may be used for research, teaching and private study purposes. Any substantial or systematic reproduction, re-distribution, re-selling, loan, sub-licensing, systematic supply or distribution in any form to anyone is expressly forbidden.

The publisher does not give any warranty express or implied or make any representation that the contents will be complete or accurate or up to date. The accuracy of any instructions, formulae and drug doses should be independently verified with primary sources. The publisher shall not be liable for any loss, actions, claims, proceedings, demand or costs or damages whatsoever or howsoever caused arising directly or indirectly in connection with or arising out of the use of this material. 
are we now

living in the Anthropocene?

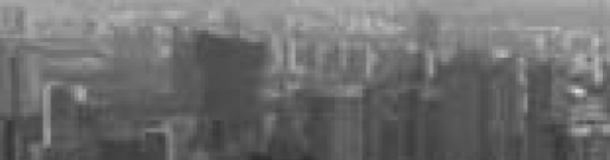

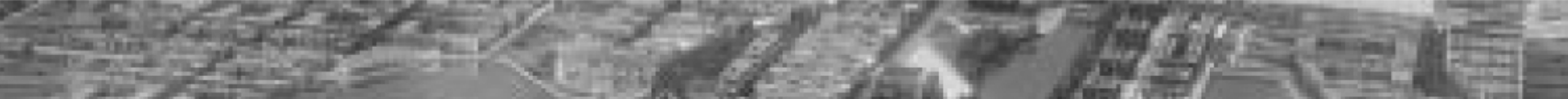

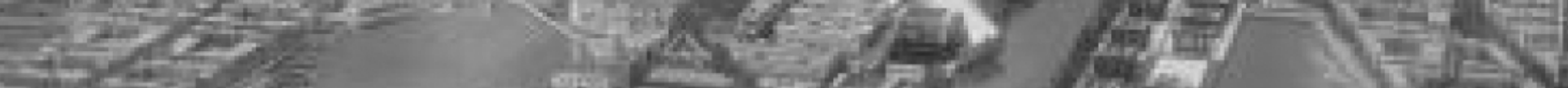

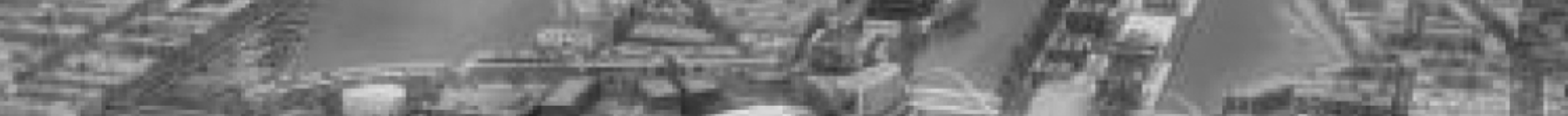

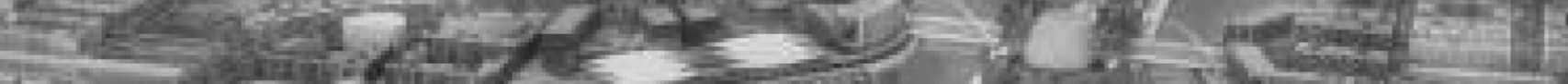

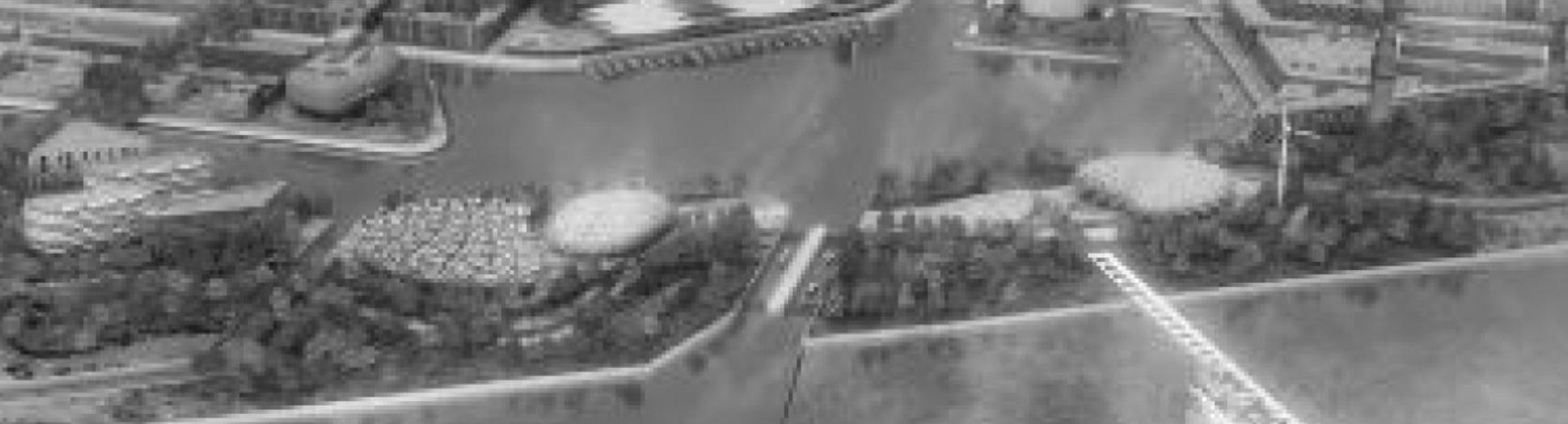




\title{
Urbanism in the anthropocene Ecological urbanism or premium ecological enclaves?
}

\section{Mike Hodson and Simon Marvin}

\begin{abstract}
Earth scientists now argue that the current geological era should be re-named the anthropocene to better reflect the impact of humans in reshaping planetary ecology. Urbanism encompasses the social, economic and political processes most closely linked to the rapid transformation of habitats, destruction of ecologies, over use of materials and resources, and the production of pollutants and carbon emissions that threaten planetary terracide. Consequently, the key concern for 21st-century global urbanism is to critically understand the wider societal and material implications of strategic responses to the pressures of climate change, resource constraint and their interrelationships with the global economic crisis. Eco-cities, eco-towns, eco city-states, floating cities and the like represent particular, and increasingly pre-eminent, forms of response. These types of response appear to promote the construction of ecologically secure premium enclaves that by-pass existing infrastructure and build internalised ecological resource flows that attempt to guarantee strategic protection and further economic reproduction. If this is so this raises difficult issues as to what is left for those outside of these privileged enclaves. The search for more equitable and just forms of response requires understanding what types of alternatives to such bounded and divisible ecological security zones could be developed that contribute towards the building of more inclusive collective planetary security. In this respect, the aim of this paper is to ask: what styles of urbanism do these transformations contribute to the production of, what are the consequences of these emerging styles and what alternatives to them are being constructed?
\end{abstract}

Key words: anthropocene, ecological urbanism, premium ecological enclaves, climate change, resource constraint

\section{Introduction}

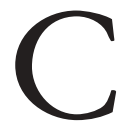
ities are critical sites in understanding global ecological change. Critically, cities are often simultaneously represented as being: significant contributors to the 'cause' of climate change, where urban areas and their inhabitants may be responsible for up to $75 \%$ of global energy consumption and carbon emissions; as foremost amongst the 'victims' of climate change, particularly the vulnerable coastal megacities of the global south; and as key sites of innovative response', such as through the actions of the representatives of large cities in the C40 network. ${ }^{1}$ All cities face the critical challenge 
of how to ensure that they can guarantee their long-term ecological and economic survival in a context of human-made global ecological change that implies greater degrees of uncertainty about climate change and the availability of critical resources such as food, water and energy (see Dalby, 2007).

Strategically we are particularly interested in trying to understand whether global ecological change, climate change and emerging resource constraints lead to particular types of urban responses and to what extent these responses imply quite different conceptions of the future of cities (Hodson and Marvin, 2009). New styles of development projects often called eco-cities but replicable to other scales-eco-regions, eco-blocks, eco-towns, eco-villages-are emerging as responses to ecological pressures. These responses have at their core the claim that they are able to transcend conventional notions of ecological constraint-climate change and resource constraint-as they build ecological security by internally producing their own food, energy and other critical resources.

Our interest in this paper is in whether such responses to environmental crises and resource constraints are based on the desire to develop relative autonomy for a city through seeking to withdraw from reliance on national and international infrastructure, to by-pass uncertain and vulnerable resources and develop local resources creating a form of bounded security; or alternatively, whether responses to constraint are based on a wider concept of social needs, the right to a minimum level of energy service, and more collective ecological security that addresses the needs of all communities and attempts to build a concept of global security. In this paper, we critically assess emerging responses and the unsettling implications they have for the conception of our collective rights to the city (Harvey, 2008).

The rest of the argument in this paper is structured in five sections. First, we review the distinctive challenges of cities in the anthropocene through an exploration of the complex relationalism between urbanism and global ecological change and the way in which questions around ecological reproduction become strategic to cities. Second, we provide an overview of exemplary and emblematic responses to these challenges at a range of scales assessing the degree to which new urban forms are seeking to transcend conventional ecological constraints through internalised and relocalised metabolic flows. Third, we ask a series of critical questions about the claims for transcendence and replication of these new styles assessing the degree to which they aspire to create ecological enclaves rather than collective planetary security. Fourth, we identify the main features of two competing logics of ecological urbanism that remain separate and largely disconnected from each other. Finally, the conclusion summarises the argument, reviews its critical implications and identifies further research challenges.

\section{Urbanatura in the anthropocene}

Cities are the material representation of today's energy-intensive economies where carbon-based energy systems-oil, electricity and mobility systems-have made the huge agglomerations of cities and modern industrial systems possible. Urbanisation totally dominates the huge metalogistical systems made up of resource flows, energy, water, waste foods as well as flows of people and goods that make up the contemporary world. The prefix 'meta' helps to view the city as an active intermediary, which sits as a site of material transformation that anticipates, modifies and excretes the movement of resources, materials and people. Cities are connected through intensive airline networks, logistical transportation systems, enormous energy and water grids as well as communication and ICT systems that facilitate interconnecting markets, production and consumption systems, people, organisations and governments. Yet in the contemporary period there is now a recognition that these industrialised systems-not all located in 
cities, but certainly largely controlled by organisations located in large global citieshave ecological affects that are beginning to change the global ecological context within which cities attempt to ensure their continued reproduction (Luke, 2003).

Consequently, geologists have suggested that a new epoch has begun which they call the anthropocene (see Zalasiewicz et al., 2008). It is proposed that this is the result of human actions whose critical markers include disturbances of the carbon cycle and global temperature, ocean acidification, changes to sediment erosion and deposition, and species' extinctions. This period coincides clearly with the development of industrialisation and the global growth in urbanisation that resulted in an estimated $50 \%$ of the world's population living in urban areas by 2000 (Figure 1).

Increasingly then there is recognition that the metalogistical systems that make the very notion of cities possible are actually reshaping global planetary ecologies through resource depletion, carbon production and pollution. In turn these effects themselves reshape the context within which contemporary cities then have to ensure their own economic (and ecological) reproduction. It is possible to see that there are multiple ways that cities can be represented in relation to climate change and resource constraint, but that these need to be understood through an existing system of uneven economic divisions of labour between and within cities.

While cities exist within a highly unified and integrated global space of capital flows, particular cities vary widely in their access to ecological resources. Highly energy-intensive urban environments in the USA contrast with the cities of the global south, where millions do not have access to clean water, energy and basic telephones. The USA has only $4 \%$ of the world's population but it

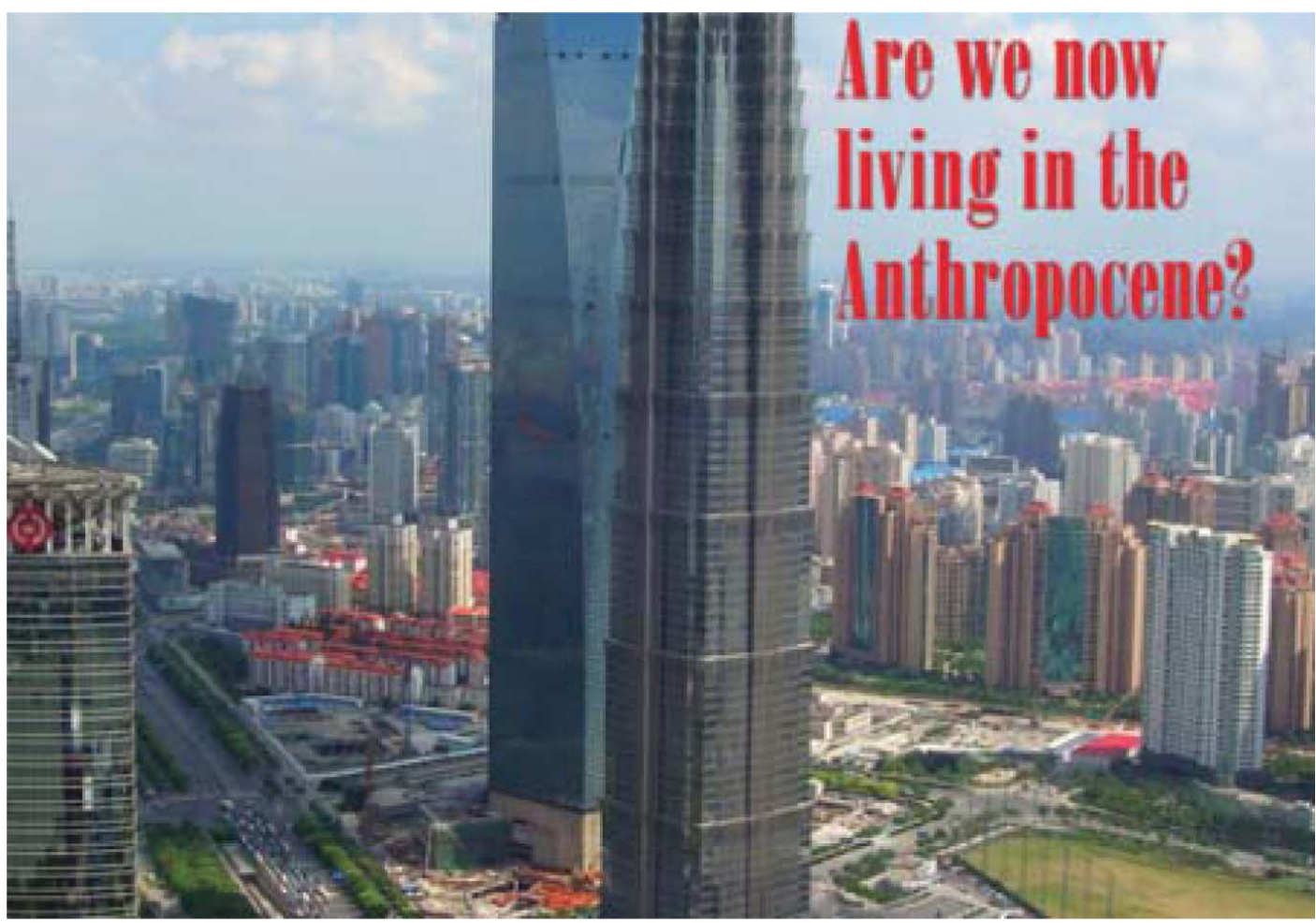

Figure 1 Cover of Geological Society of America. 
generates around $25 \%$ of global greenhouse gas emissions (Soubbotina, 2004). Americans' ability to tap into and control global ecosystems of fossil fuels means that US cities are able to be far more spatially expansive and destructive than if they had to survive solely on the resources available in their national space. Clearly then, global cities are able to exert control over critical resources in competition with residents and refugees in other less important and more ordinary cities. $^{2}$

Consequently, we would expect significant differences in the capability of cities to respond effectively to energy security and climate change. A critical issue is which cities encompass the resources, knowledge, expertise, social and institutional relationships and wider governance capacity to shape systemic and managed (rather than project and piecemeal) change in the social and technical organisation of their cities and infrastructure. Anthropocenic change creates a new urbanatura-a much more unpredictable context for the longer term development and reproduction of cities marked by climate change, implications for resource constraint, as well as energy, water and food security issues (see Luke, 2008). Now, cities' ability to ensure their longer term economic and material reproduction will be dependent on their capability to guarantee their ecological security and access to energy sources under the changed ecological conditions of climate change and resource constraint.

The term 'ecological security' is usually used in relation to attempts to safeguard flows of ecological resources, infrastructure and services at the national scale. But increasing concerns over 'urban ecological security' are giving rise to strategies to reconfigure cities and their infrastructures in ways that help to secure their ecological and material reproduction. By this we mean the capacity that cities can mobilise to secure the resources (such as water and energy, but also including waste disposal and protection from flooding) required to ensure their continued economic and social development. ${ }^{3}$ Such concerns are also increasingly becoming issues at an urban scale, for three interrelated reasons. First, increasing economic globalisation and the changing relationships between national and subnational territories and economic activity have led to new state spaces of governance and intervention (Brenner, 2004). Second, the development of these new state spaces has not received the same attention in relation to environmental concerns as it has with regard to economic activity. Finally, there is the issue of how the economic and ecological reproduction of cities can be secured in a context of rapidly growing population, high demand for resources amid increasing resource constraints, and intense competition for economic activity and jobs.

Increasingly, cities are developing more strategic approaches to meeting future resource requirements, to enhance their standing in the inevitable competition between places, but more profoundly, to provide the conditions that can assure their continuing social, economic and material reproduction. This reflects a shift from the post-9/11 agenda of critical infrastructure protection from terrorism or the consequences of environmental damage to a focus on safeguarding a city's material resources. A new dimension of cities' competitive positioning is their ability to internalise and control both the resources with which they are endowed and subsequent supply, consumption and production. The knowledge, expertise, social organisation and socio-technologies required to maintain cities' economic and social roles are thus likely to be defining features of 21st-century urbanism. But what actual strategies will be adopted?

\section{3. 'Integrated eco-urbanism'}

A set of emerging responses are primarily concerned with attempts to construct integrated responses to infrastructure that cut across multiple infrastructure networksenergy, food, water, waste, etc.- -and that are rebundled together at particular scales in the design of new buildings, neighbourhoods, 
towns, blocks and cities. These usually focus on new-build developments, either entirely new 'greenfield' developments such as an eco-city or eco-town or sometimes new standalone developments that are located adjacent to or within existing cities such as an eco-house or eco-neighbourhood. This style of development is much more concerned with integration at the scale of the development than with the wider transformation of the existing city or its incumbent infrastructure networks.

These responses have at their core the vision and aspiration that they are able to transcend conventional notions of ecological constraint-climate change and resource constraint-as they build ecological security by internally producing their own food, energy and other critical resources, reusing wastes as resources and reducing reliance on external infrastructures. The examples we detail below and synthesise draw upon the most 'exemplary' illustrations of this new style of urbanism that are claimed by their developers to offer the new and replicable models of development. We allow the developers-the consultancies, engineers, architects-to describe their concepts and their replicability through their own words, statements and representations of space. A pattern starts to emerge within which particular coalitions of social interests-consultancies, architects and engineers sometimes with elements of the green movement-are collaborating with particular place-based interests in the development of new infrastructural fixes.

\section{Eco-towns}

Eco-towns are a programme of supposedly exemplar sustainable new towns to be built in England. The wider context for the ecotowns programme is the UK Government target to build 240,000 new homes per annum by 2016 and to reduce $\mathrm{CO}_{2}$ emissions by $80 \%$ below 1990 levels by 2050. Consequently it is intended that eco-towns

\begin{abstract}
'should make a significant contribution to these targets and help address the serious threat of climate change [and] should be exemplar projects that encourage and enable residents to live within managed environmental limits and in communities that are resilient to climate change'. (DCLG, 2009, p. 2)
\end{abstract}

In 2007, the UK Department of Communities and Local Government (DCLG) announced a competition to build up to 10 eco-towns. Initially over 50 bids were submitted and in mid-2009 the Government eventually gave the go-ahead for the construction of four eco-towns, providing 10,000 new houses. Eco-towns are meant to reach new ecological standards that are 'more challenging and stretching than would normally be required for new development' and are designed to act as 'exemplars of good practice’ (DCLG, 2009, p. 1). More specifically, this relates to the intention that in eco-towns: energy emissions specifically related to the built environment will need to be 'zero or below'; development will need to be 'resilient to and appropriate for the climate change now accepted as inevitable'; they are ambitious in terms of water efficiency and in areas of water stress and should aspire to water neutrality-that is, build new developments without increasing overall water use in the wider area by managing demand downwards; and that they should consider using locally generated waste as fuel sources for combined heat and power regeneration for the ecotown $(2009$, p. 3$)$.

\section{Eco-blocks}

Eco-blocks are designed as urban gated communities. An eco-block aspires to be 'resource self-sufficient (i.e. carbon neutral) in its operation (or close to it), and if it could replicate and spread throughout the world, this would be a major force in reversing global climate change' (Fraker, 2006, p. 44). The eco-block project has been developed as an alternative to China's typical 'gated super 
block' development model which are and have been dependent on central infrastructure support in the form of electric power plant generation and distribution, sewage collection and treatment, water treatment and distribution, and waste collection and disposal. China is currently hard pressed to satisfy the infrastructure demands of the super block model. In contrast, the eco-block is designed in an integrated whole-systems approach to generate all its energy from onsite renewables, to recycle all of its water and to recycle over $80 \%$ of its waste for onsite uses. In addition, it is designed to provide convenient pedestrian and bike access to a new bus rapid transit system located on a major adjoining road network. The designers claim that the eco-block's whole-systems approach is flexible and adaptable to multiple local conditions and climates and is 'widely replicable throughout China'. ${ }^{4}$ The aim is that the 'neighbourhood becomes essentially a self-sufficient unit, a circular system. It does not require the construction of expensive new power plants, new sewage treatment and new water supply outside the system' (Fraker, 2006, p. 49). Although the block does not have to be connected to the grid for energy and is self-sufficient in water, the waste cycle is not totally closed and approximately $20 \%$ of waste will need to be disposed outside the system. Arup, the engineering firm, are now partnering the University of
Berkeley to develop an eco-block as a demonstrator with the stated intention of replication of this throughout China.

\section{Eco-islands}

Eco-islands provide a different scale, again, at which attempts are underway to construct more self-reliant forms of urban development using decentralised technologies and recirculating resource flows. Islands offer a number of benefits in developing these types of solutions; in particular, that there is a clear boundary that provides a high degree of clarity about the direction and scale of resource flows; often governance structures may be more unified and simplified so that infrastructural priorities can be more easily designed into the scheme, implemented and monitored; and there is a defined range of publics and stakeholders to engage with on new infrastructure solutions. Consequently, islands have traditionally been used as sites of experimentation for a number of infrastructure experiments, such as the testing out of the conversion to natural gas and piloting water metering on the Isle of Wight off the south coast of England.

Treasure Island is a former naval air base built on 400 acres of reclaimed land in San Francisco Bay in the 1930s (Figure 2). By 2020 it is planned to become one of the most

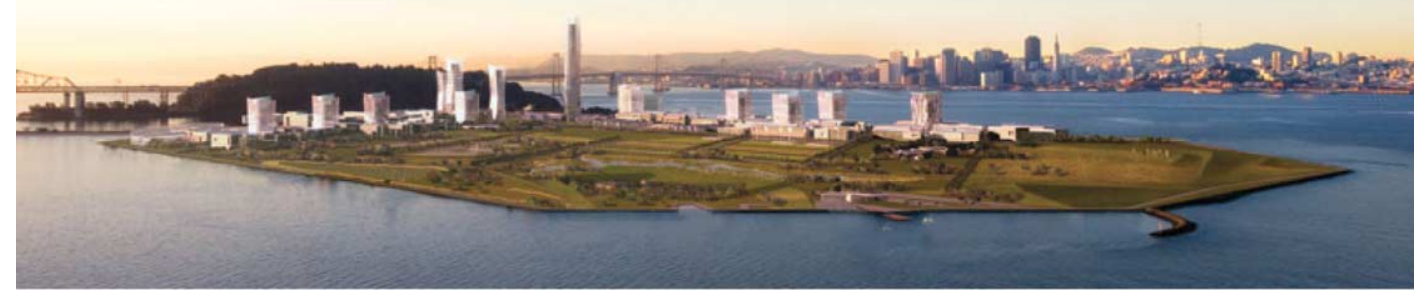

Figure 2 Treasure Island. Source: Arup. 
sustainable communities in the USA with 6000 new apartments and businesses. Over $50 \%$ of the power, it is claimed, would be from renewable resources, including solar electricity and solar water heaters, the street grid has been designed to maximise the exposure of the rooftop photovoltaics to sunlight and all the buildings would be within a 15minute walk of a ferry terminal to San Francisco. It is intended that residents could obtain much of their fresh produce from a local organic farm that would use as fertiliser the waste from a water treatment plant already on the island. Even so, the development would not feasibly be net carbon-zero given the tensions between the available technology and the need for the owner to make a profit. There are, however, other aspirations to design zero-carbon islands. The island country of Tuvalu, for example, located halfway between Australia and Hawaii in the middle of the Pacific Ocean and-with most of the country only one metre above sea level-highly vulnerable to climate change and sea-level rise plans to abandon fossil fuels and generate all of its energy from renewable sources by $2020 .^{5}$

\section{Eco-cities}

In 2005 Arup, the global planning, engineering and design consultancy, signed a contract with the Shanghai Industrial Investment Corporation (SIIC) to plan the world's first sustainable city - an eco-city-at Dongtan, in Shanghai, China (Figure 3) (Arup, 2005). Dongtan is situated in a strategic position very close to Shanghai and on the third largest island in China, located at the mouth of the Yangtze River. Dongtan is three-quarters the size of Manhattan and is designed as a sustainable city to attract a whole range of commercial and leisure investments to what is currently a large area of mostly agricultural land. The aim is that all Dongtan's buildings are powered by renewable energy and that it is self-sufficient in water and food sourced from the surrounding farmland. The 630 hectare first phase of the city aspires to house up to 80,000 people by 2020 and inhabitants will be encouraged to make use of the zerocarbon public transport, which will be powered entirely by renewable energy (Arup, 2006). Arup Director, Peter Head, has claimed that the scheme 'could well prove to be the template for sustainability in city planning-not only in China, but elsewhere in the world' (Arup, 2005).

A second-generation movement of ecocities exemplified by Masdar, in the United Arab Emirates (UAE), is now seeking to challenge Dongtan's status as the world's first eco-city. Masdar translates as 'the source' and has aspirations to be 'zero carbon' and 'zero waste'. Seemingly paradoxical for a sheikdom built on oil wealth, carfree Masdar will have a point-to-point transport system based on 'Subterranean electric cars-dubbed Personalized Rapid Transit'. Masdar already has a solar power plant under construction in the deserts surrounding it to provide electricity for lighting and air conditioning and for desalinating ocean water. This latter point is a most important one and links to Masdar's strategy of recycling all water. Additionally, energy will be generated through wind farms and geothermal energy (Biello, 2008).

\section{Eco-regions}

The Thames Gateway is a £9 billion project that would span 40 miles along the River Thames from London's Canary Wharf to Southend in Essex and Sittingbourne in Kent (Figure 4). It could be 'Europe's largest regeneration project' and the UK Government has also repeatedly said it wants the project to be an example of responsible environmental development to the rest of the world. Consequently, the Thames Gateway is proposed as an 'eco-region' using new environmental technologies and higher environmental standards than previous UK development projects. The eco-region designation includes energy-saving modifications 

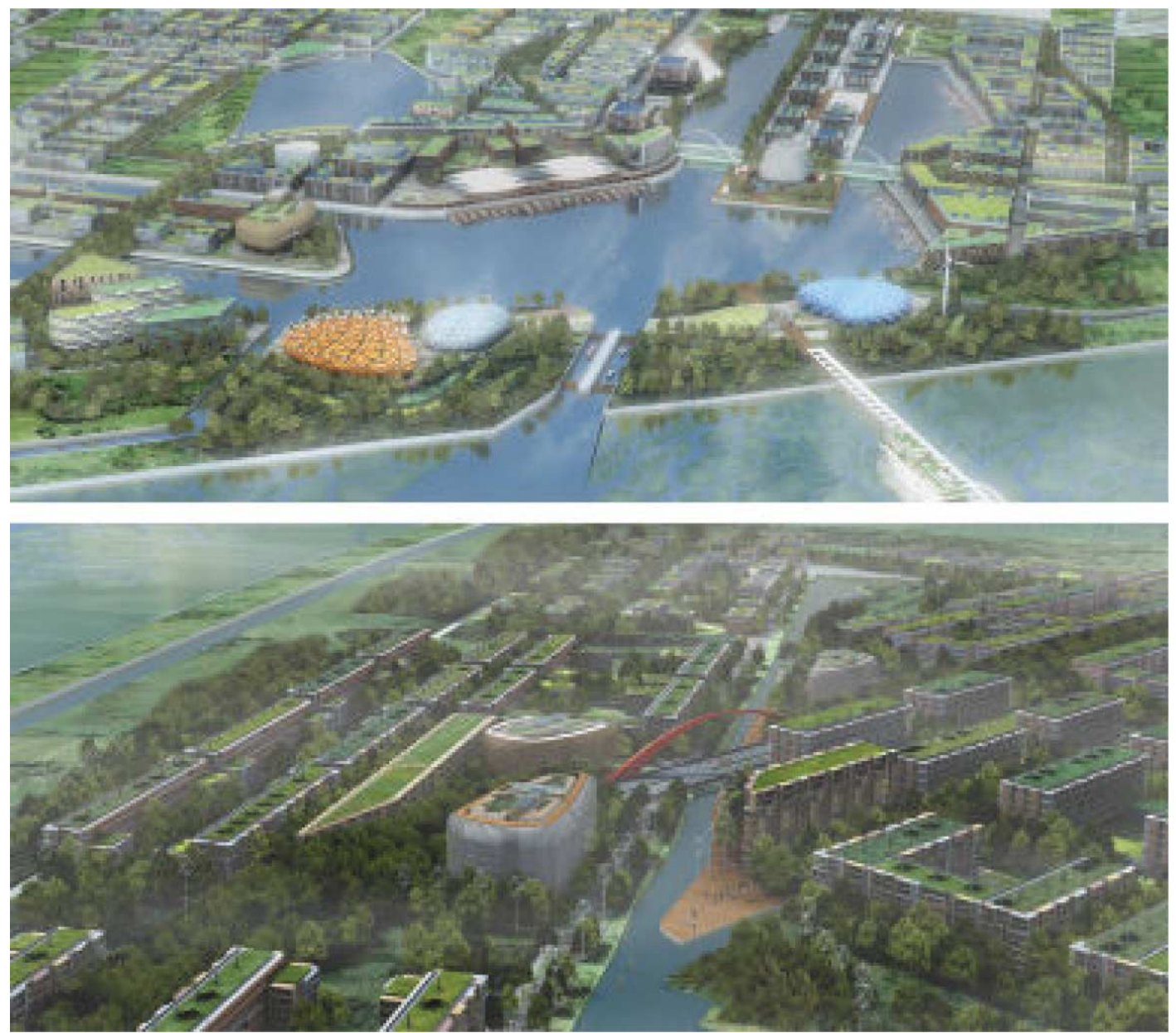

Figure 3 Dongtan 'the world's first sustainable city'. Source: worldarchitecturenews.com

to reduce the carbon emissions of existing homes in the region by $60 \%$. Newly built homes would be completely carbon neutral. Of particular interest is the assertion that the project can be water neutral through the application of an intensive water management system that is to be put into place in both existing and new homes (Environment Agency, 2007). This would include the use of water-saving appliances, variable-flush toilets, low-flow showerheads and low-flow faucets. Additionally the proposal includes plans for what would be two of the largest offshore wind generation dams in the world and a biomass generation plant for energy. Thames Gateway would also be incorporated into the Olympic site plans for 2012 and Cross Rail, a proposal to expand the current UK rail system with a new high-speed underground railroad across London and the South-East to be completed by 2017.

\section{'Alternative' responses}

There are also other debates about relocalisation that include wider sets of social interests and try to put other social objectives on the urban policy agenda. These include Low Impact Urban Developments, Transition Towns and Relocalisation movements being developed as local social and behavioural 


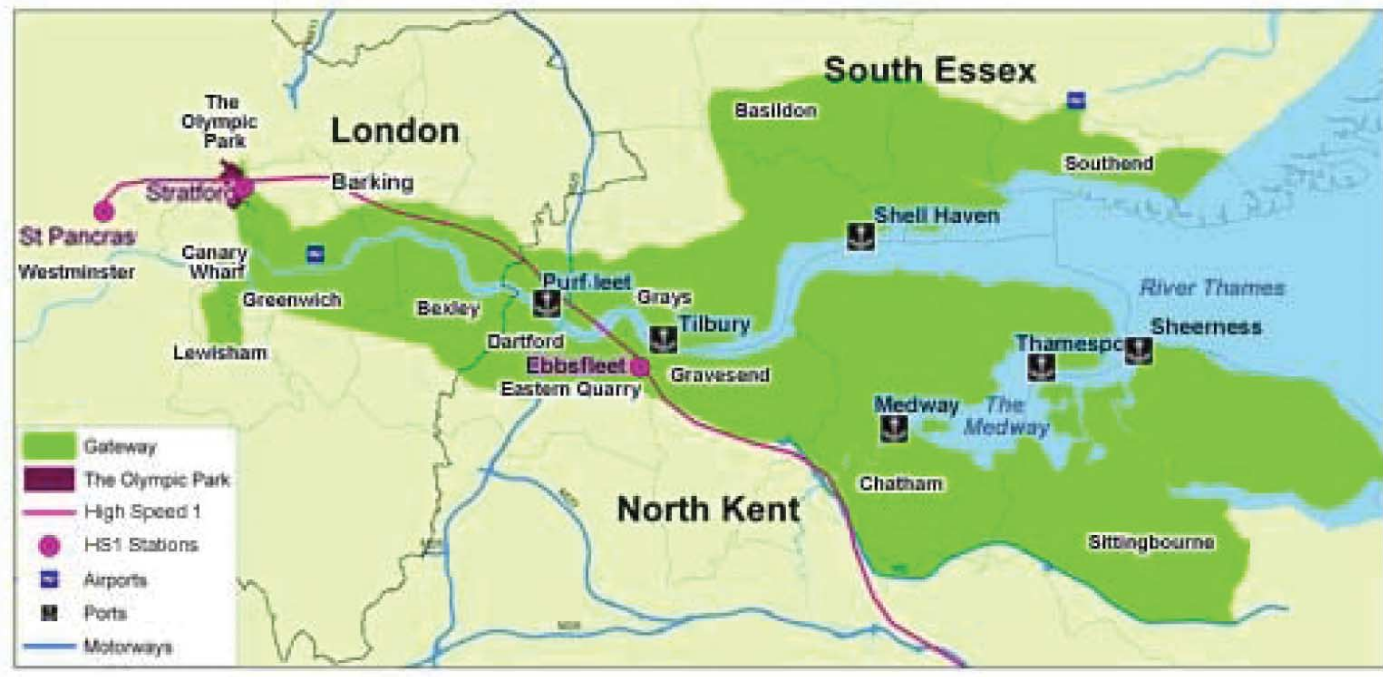

D.

30

60 Kilometres

Q Crown copyright All rights reserved DCLG 10001189682006

Figure 4 Thames Gateway 'eco-region' near London. Source: DCLG.

responses in a number of urban contexts in the UK and USA. Low Impact Urban Development (LID) encompasses a range of community-based initiatives that seek to internalise infrastructure and resource flows. LID is important as a site of practical innovation and attempts at low-carbon living (Pickerill and Maxey, 2009). Although there are important similarities between LIDs and the more commercially and governmentally oriented integrated eco-developments outlined-in particular, the emphasis on autonomy, the development of local technologies, circular metabolisms and the aspiration for greater self-reliance-there are also some significant differences. In particular, LIDs stress local and community control of infrastructure and raise wider issues about ensuring more equitable access to environmental resources for low-income households. There are now dozens of Transition Towns in the UK which operate on the basis of a shared methodology to develop a locally 'coordinated range of projects across all these areas of life [that] leads to a collectively designed energy descent pathway'. ${ }^{6}$

Such strategies seem to imply a more collective approach to innovation around climate change and resource constraints not solely oriented around technical fixes, and a more socially and culturally driven approach to new solutions and configurations. Critically, these are designed in context and cut across all aspects of urban life. A key focus is on resource reduction rather than reproducing the productivist bias of commercial approaches. To take another example, a US network draws together over 172 urban post-carbon groups worldwide. ${ }^{7}$

How particularly we understand integrated eco-urbanism-as what sorts of artificial reconstructions of nature and ecology through design and technology-is critical. That is to say, it is what specific responses amount to that is important: whether they are responses to a set of specific historicgeographic pressures, a new means of political-economic reproduction or a cultural representation of a more ethical urbanism. Our point is that they represent a specific spatial and temporal project in which ecology and economy merge around technoscientific design. To understand why this is the case, we need to locate eco-urbanism within a wider understanding of what is happening to global urbanism. 


\section{Eco-urbanism as divisible or collective security?}

Ecological urbanism provides an opportunity to ask important questions about the wider societal implications and potential long-term consequences for our understanding of eco-cities. As urbanists, our primary interest in this study is in looking behind the interests promoting eco-urbanism as a specific temporal and spatial response to the challenges of climate change and resource limits. What most concerns us is the questionable assumption that eco-urbanism is a transformative style of development that will allow cities to continue to grow economically while quite literally transcending environmental constraints, obviating the need for wider societal change. Does eco-urbanism represent merely an attempt to create ecologically secure gated communities, or can it contribute to the development of more collective notions of planetary security in the face of multiple eco-emergencies?

\section{Normalising replicant eco-urbanism}

The new eco-urbanism appears to have gone mainstream, developing its own lexicon of scales through which new projects are implemented around the globe; there are ecovillages, eco-towns, eco-blocks, eco-islands, eco-cities and even eco-regions (see Figure 5). But although many developments have not even left the drawing board, there is enormous enthusiasm for replicating eco-city developments, represented as visionary-and exemplary-experiments. ${ }^{8}$ The IEEE Spectrum sees eco-cities as 'a city-scale test bed' for re-engineering technologies to maximise efficiency and reduce environmental waste, while Herbert Girardet, the ecologist urbanist and advisor to Arup, argues that 'Dongtan is intended to set an example. It will be a pioneering eco-city that could become a blueprint for sustainable urban development, in China itself and elsewhere in the world' and that by 2010 'Dongtan will be a compelling

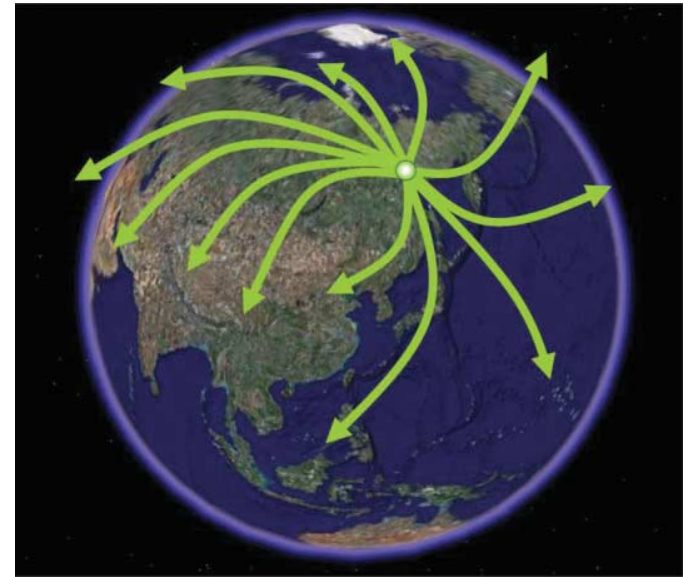

Figure 5 The eco-block-a model for sustainable development around the world?

model for how to build sustainable cities worldwide that may well be too persuasive to ignore'.

Although there is relatively little experience of actually building eco-cities and assessing whether the social visions and technological aspirations are achievable, there are already intergovernmental agreements (for instance, between China and the UK) to accelerate the development of eco-city development in both contexts.

\section{Integrated (quasi) autonomous infrastructure}

The new network infrastructure of ecourbanism seeks to integrate environment and infrastructure by rebundling architecture, ecology and technology in an attempt to internalise energy, water, food, waste and material flows within the development. Engineers, systems modellers, material flow analysts and designers are involved in integrating local production technologies, circular metabolisms and closed-loop systems to reduce reliance on external centralised infrastructure networks. This places a particular premium on low-water-use systems, water recycling, reuse of waste water, local energy production systems, reuse of waste and local food production systems. These responses strongly echo the early integrated system 
models of the 1970s; what is different this time is the extension of these systems to consider carbon flows and the impact of climate change, along with aspirations to explore new concepts such as carbon neutrality, waste neutrality and water neutrality. Significantly, there seems to be much less debate in this current period about wider questions of social and institutional control of these technologies, which, it is largely assumed, will be provided by the market.

\section{Eco-cities as test beds for mobile financial products}

Common to these different developmentspromoted by different sets of commercial, developer, architectural and engineering interests-is the notion of test beds, demonstrations or experiments of what might constitute new models of sustainable cities. Critically, it is not clear whether at these scales it is possible to achieve their energy and ecological objectives, given the disappointments with large multi-user buildings. But these developments are also designed to be financial as much as eco-technical projects. Masdar's property developer was quoted as saying: 'We want Masdar city to be profitable, not just sunk cost. If it is not profitable as a real-estate development, it is not sustainable' (added emphasis, quoted in Bullis, 2009). The intention is to develop new models of development whereby the developer can extract value from being an infrastructure provider through internalising and commodifying resource flows within the development. Ultimately the objective is to turn the whole development process, including the energy and infrastructure, into a single financial product that is replicable in other contexts. In this sense eco-urbanism may represent an attempt to build privatised and bounded ecological spaces that can anticipate and transcend ecological constraint and climate change for their users. Consequently, there are clearly limits involved in developing transcendent urbanism. While it may be possible to create contexts where it is commercially viable this is likely to mean these are designed, in the case of Masdar, 'as a playground for the rich’ (Friend quoted in Bullis, 2009).

\section{Eco-urbanism as transcendent urbanism}

Linked to the aspiration of greater ecological and infrastructural self-reliance is the claim that eco-urbanism can develop cities in almost any urban context, overcoming both local environmental limits and the consequences of global climate change and resource constraints. So, for example, we have Masdar being developed in the desert of the UAE; Dongtan being built adjacent to an internationally significant wildlife site in Shanghai; and the water-stressed, polluted brownfield and flood-risk sites of the Thames Gateway being designed to accommodate an additional 160,000 houses through a combination of water, waste and carbon neutrality, along with unprecedented levels of flood protection. Cities, according to some visions, will even be constructed in the oceans. Ecourbanism is a new style of urbanism that provides the technological solutions and market frameworks to overcome what we would have conventionally understood as limits while anticipating a period of climate change and ensuring continued reproduction under a period of resource constraint. Given impending eco-emergencies, eco-urbanism will attempt to provide a guarantee that it can transcend any ecological circumstance.

\section{Corporate and governmental leadership of eco-urbanism}

Leadership of the eco-urbanism movement is strongly focused around particular corporate and governmental interests. This is in stark contrast to the 1970s, when at least part of the response by radical and environmental groups was a critique of such interests. For example, General Electric is the strategic partner in Masdar, which is designed to place the UAE 
in a global leadership role with respect to renewable and environmental technologies. The British engineering firm Arup, which is developing Dongtan, has signed agreements with the Chinese and UK governments to establish a series of linked Institutes for Sustainability - the first being developed in the Thames Gateway in London-to develop the expertise and institutional frameworks to roll out eco-urbanism. Environmental and green groups, such as Greenpeace and the World Wildlife Fund, are now supporters or partners with commercial and governmental actors involved in accelerating the construction of eco-urbanism.

\section{Competing logics of eco-urbanism}

Urban responses are being developed in two quite different ways. First, there are a set of responses to these pressures focused on the development of 'new-build' ecodevelopments. The second set of responses focus on more bottom-up communitybased approaches around relocalisation. Table 1 compares these approaches-let's look at each of these in turn in more detail.

For the initiators of these new ecodevelopments it is critical to develop and test new models of urbanism and then roll these out in other contexts as a form of replicant eco-urbanism. Yet these new models assume a number of key features that raise worrying issues about the degree to which we can talk about fair cities. First, they are being developed by a limited range of commercial interests who explicitly seek to develop eco-cities as potentially replicable global financial products that can be developed in any context transcending ecological limits. Second, their success is partially measured in the degree to which they can be profitably reproduced, therefore reducing their replication to specific market-based circumstances which in any case will be developed for elites in order to help ensure their replicability. Third, they are strongly technocratic and productionist-oriented, and fit logically with the claim that it is possible to carry on reproducing cities-largely without changing the organisation of society or the economy by incorporating clever eco-technics within the design of cities. Given such issues, one wonders about the relevance of new styles of urbanism which are promoted for their ability to remarkably transcend eco-limits yet at the same time do so in such a socially regressive and market-oriented way where success is reduced to their economic replicability!

Our concern then is that eco-cities represent one particular response to the problems of climate change, resource constraint and energy security in a period of particular ecological emergency and economic crisis. As such we should see them as the purest attempt to create neo-liberalised environmental security, not at the scale of the whole

Table 1 Urban responses compared

\begin{tabular}{|r|c|l|}
\hline Bounded Responses & Feature & 'Alternative' Responses \\
\hline Transcendence of limits & Ecological constraints & Work within limits \\
\hline $\begin{array}{r}\text { Commercial }- \text { banks, developers } \\
\text { architects, utilities }\end{array}$ & Social interests & $\begin{array}{l}\text { Community }- \text { NGOs, } \\
\text { environmental groups, charities }\end{array}$ \\
\hline Divisible & Concept of security & Collective \\
\hline $\begin{array}{r}\text { Eco-urbanism - eco-cities, regions, } \\
\text { blocks and towns }\end{array}$ & Scale of solution & Consumption - small, local \\
\hline $\begin{array}{r}\text { Product of bounded security and } \\
\text { by-pass }\end{array}$ & Consequences & Retrofitting - existing and new \\
\hline $\begin{array}{r}\text { Dongtan (Shanghai), Masdar } \\
\text { (UAE) }\end{array}$ & Exemplars & Transitions towns, Relocalisation \\
\hline
\end{tabular}


city or even the planet, but a more bounded divisible security in order to try to guarantee ecological security for elites.

But there are also other debates about relocalisation that include wider sets of social interests and try to put other social objectives on the urban policy agenda. These include Low Impact Urban Developments, Transition Towns and Relocalisation movements being developed as local social and behavioural responses in a number of urban contexts in the UK and USA. Such strategies seem to imply a more collective approach to innovation around climate change and resource constraints not solely oriented around technical fixes, and a more socially and culturally driven approach to new solutions and configurations. Critically, these are designed in context and cut across all aspects of urban life. A key focus is on resource reduction rather than reproducing the productivist bias of commercial approaches. This implies a more critical view of our reliance on energy and the implications this has produced. Evidently, there would be significant worth in looking further at such alternatives and how they compare and contrast with the strategies involved around eco-cities. There would be value in contrasting the different logics in terms of the social interests, the solutions developed, the balance between productionist and demand solutions and the implications of such strategies. More widely, there would be benefits in considering how other constructions could be based on concepts, such as mutual interdependence, relationality, trading and trade-offs, fair shares and environmental justice.

\section{Conclusion}

There are then a range of critical pressures to re-internalise energy and other infrastructure flows within the conception of urban development. A new set of eco-technics are attempting to develop internalised metabolisms that are simultaneously an attempt to build ecological security for the few and to create new mobile financial products as integrated urban development as a new opportunity for capitalist reproduction. Our argument is that the dominant logic of neoliberal responses is about the creation of 'bounded' security in new ecological enclaves for premium users that ignore wider distributional questions about uneven access to resource politics. These are the ecologically secure gated communities of the 21 st century that seek to internalise ecological resources and build strategic protection from climate change and wider resource constraints.

Consequently, at the moment markets for new eco-developments are likely to only exist in premium sites - that is, world cities-where the premium product that is produced is largely irrelevant to the claims of reproducibility made by their proponents. It is likely that eco-funding through bailouts may be used to accelerate the development of such solutions in an attempt to reconfigure capitalist urban development. Of course, such premium ecological environments have relatively little to offer the real challenge of re-engineering and systemically retrofitting existing urban environments to reduce energy and water use, accelerate low-carbon technologies, and provide affordable energy for all users.

At the same time it is not even clear if the claims made about the new self-reliant and autonomous developments are achievable. There is a long history of eco-buildings and districts not achieving the savings claimed for them as users behave in unanticipated ways. In any case we are usually only talking about forms of greater autonomy and self-reliancetherefore only relative forms of 'by-pass'. Will centralised infrastructure networks act as the provider of last resort when local technologies fail? Critically, what about forms of mobility-especially internationally-how will these be provided?

In contrast to these conventional responses there are alternative movements that are less commercially focused, more locally based, less technologically fixated that are also trying to put questions about relocalisation 
back onto the urban agenda. Movements such as green jobs, Transitions Towns and Relocalisation are trying to develop an alternative discourse around greater self-reliance. But what is part of this discourse are questions of social control-technology for whom by whom-attempts to link investment to local need, the development of interdependencies and mutuality rather than securitisation, although these are more marginal and external to the dominant responses.

Finally, if we are to build fair cities that advance collective planetary security we need to think about linking these disconnected logics of development together. Rather than allowing a dominant security-led approach to sit alongside a much more marginal set of approaches we need more interaction in the following five ways. First, to bring together questions about which social interests are involved and excluded-we need to bring users back into questions about resource futures. Second, to bring together overtechnicised and over-socialised responseswe need progressive socio-technical change. Third, to develop knowledge and expertise that is not just about 'new-builds' and security, but about retrofitting the existing city. Fourth, we need to emphasise questions about need and the politics of interdependencies rather than bounded security for some. Fifth, it is crucial to develop a debate about the consequences of a new style of urbanism rather than the creation of new urban ecotechnic and financial products as a response to ecological crisis.

\section{Acknowledgements}

We are grateful to our colleagues in SURFTim May and Beth Perry-for their support in developing the ideas in this paper and to Vivian Liang for excellent help in securing the permissions for the figures and photographs illustrating this contribution. Thanks to two anonymous referees who provided useful and constructive comments on a previous draft of the paper.

\section{Notes}

1 The $\mathrm{C} 40$ was formed in 2005 and is a group of the 'World's largest cities committed to tackling climate change (because) cities and urban areas consume 75 per cent of the world's energy and produce up to 75 per cent of its greenhouse gas emissions.' See http:// www.c40cities.org/

2 As well as the differences between cities of the North and South there are of course also significant internal differences within all cities in terms of levels of social access to critical resources such as energy, water and a clean local environment.

3 For a longer discussion of urban ecological security see Hodson and Marvin (2009).

$4 \mathrm{http} / / /$ bie.berkeley.edu/ecoblocks (accessed 21 September 2009).

5 http://www.telegraph.co.uk/news/worldnews/ australiaandthepacific/tuvalu/5871093/Tuvaluplots-worlds-first-zero-carbon-output-by-2020.html (accessed 25 November 2009).

6 http://www.transitiontowns.org/ (accessed 29 January 2008).

7 http://relocalize.net/about/relocalization (accessed 29 January 2008).

8 For example, a 'bright green metropolis'-Wired and a possible 'blueprint for green cities worldwide'-New Scientist.

9 See page 3 of 'Which Way China?' by Herbert Girardet, http://www.builtenvironment.uwe.ac.uk/research/pdf/ girardet2.pdf (accessed 15 September 2009).

\section{References}

Arup (2005) Arup unveils plans for world's first sustainable city in Dongtan, China. Available from: http://www.arup.com/arup/ newsitem.cfm?pageid=7009 (Accessed 6 May 2009).

Arup (2006) London looks to the East for inspiration to cut emissions. Available from: http:// www.arup.com/newsitem. cfm?pageid=8295 (Accessed 6 May 2009).

Biello, D. (2008) 'Eco-cities urban planning for the future', Scientific American, 24 September. Available at http://www.scientificamerican.com/ article.cfm?id=eco-cities-urban-planning (accessed June 2009).

Brenner, N. (2004) New State Spaces: Urban Governance and the Rescaling of Statehood. Oxford: Oxford University Press.

Bullis, K. (2009) 'A zero-emissions city in the desert oilrich Abu Dhabi is building a green metropolis. 


\section{CITY Vol. 14, No. 3}

Should the rest of the world care?', Technology Review, March/April. Available at http:// www.technologyreview.com/energy/22121/ page2/ (accessed June 2009).

Dalby, S. (2007) 'Anthropocene geopolitics: globalisation, empire, environment and critique', Geography Compass 1(1), pp. 103-118.

DCLG (2009) Planning Policy Statement: Eco-towns. London: Department of Communities and Local Government.

Environment Agency (2007) Towards water neutrality in the Thames Gateway. Science report: SC060100/ SR3. Available from: http:// publications.environment-agency.gov.uk/pdf/ SCHO1 107BNMC-e-e.pdf (Accessed 6 May 2010).

Fraker, H. (2006) 'Unforbidden cities: can a new type of "gated community" reverse China's ecological debacle?', California Magazine $118(5)$, pp. 44-49.

Harvey, D. (2008) 'Right to the City', New Left Review 53.

Hodson, M. and Marvin, S. (2009) 'Urban ecological security: a new urban paradigm?', International Journal of Urban and Regional Research 33(1), pp. 193-215.

Luke, T.W. (2003) 'Codes, collectivities, and commodities: rethinking global cities as megalogistical spaces', in L. Krause and P. Petro (eds) Global Cities: Cinema, Architecture, and Urbanism in a Digital Age. New Brunswick, NJ: Rutgers University Press.

Luke, T.W. (2008) 'Climatologies as social critique: the social construction/creation of global warming, global dimming, and global cooling', in S. Vanderheiden (ed.) Political Theory and Global Climate Change. Cambridge, MA: MIT Press.

Pickerill, J. and Maxey, L. (eds) (2009) Low Impact Development: The future in our hands. Available from: http://lowimpactdevelopment.wordpress. com/

Soubbotina, T. (2004) Beyond Economic Growth: An Introduction to Sustainable Development. Washington, DC: World Bank.

Zalasiewicz, J., Williams, M., Smith, A., et al. (2008) 'Are we now living in the Anthropocene', GSA Today 18(2), pp. 4-8.

Mike Hodson is Research Fellow at the Sustainable Urban and Regional Futures (SURF) Centre, UK. His research interests focus on city-regional transitions to lowcarbon economies, the ways in which this may or may not happen and understandings of the lessons to be learned from such processes. Email:M.Hodson@salford.ac.uk

Simon Marvin is Professor and Co-Director of SURF. He is an expert on the changing relations between neighbourboods, cities, regions and infrastructure networks in a period of resource constraint, institutional restructuring and climate change. Email: S.Marvin@salford.ac.uk 